\title{
Den svenske chlamydiavarianten nvC trachomatis i Norge
}

\begin{abstract}
Sammendrag
Bakgrunn. En variant av Chlamydia trachomatis (nvC trachomatis) har skapt problemer for chlamydiadiagnostikken i Sverige. Andelen nvC trachomatis i Sverige i 2006-07 var fylkesvis 25-80\% av dem som var smittet av $C$ trachomatis. Vårt formål har vært å overvåke nvC trachomatis blant våre pasienter fra januar 2007 frem til juli 2008.
\end{abstract}

Materiale og metode. 1.1. 2007-30.6. 2008 ble alle chlamydiaprøver ved Fürst Medisinsk Laboratorium dobbeltanalysert. Deteksjon av $C$ trachomatis ble utført på isolert DNA med Cobas TaqMan 48 (Roche Diagnostics). Deteksjon og verifikasjon av nvC trachomatis ble utført med egenutviklede sanntid polymerasekjedereaksjonsmetoder.

Resultater. 61 av 23726 pasienter ble identifisert som bærere av nvC trachomatis. Andelen $\mathrm{C}$ trachomatis-bærere som var nvC trachomatis-positive økte fra 1,0\% i første kvartal 2007 til 3,2\% i andre kvartal 2008.

Fortolkning. Våre resultater viser en langsom, men jevn økning $\mathrm{i}$ andelen nvC trachomatis-positive prøver. Sammenliknet med tidligere prevalenstall rapportert i Sverige (25-80\%), er forekomsten av nvC trachomatis lav i våre data. Epidemiologien til nvC trachomatis bidrar til kunnskapen om spredning av seksuelt overførbare infeksjoner og understreker at man finner bare det man leter etter.

\section{Nils Reinton}

Fürst Medisinsk Laboratorium

Søren Bulls vei 25

1051 Oslo

\section{Harald Moi}

Seksjon for venereologi

Olafiaklinikken

Oslo universitetssykehus, Rikshospitalet

og

Fakultetsdivisjon Rikshospitalet

Universitetet i Oslo

Johan Bjerner

Amir Moghaddam

amoghaddam@furst.no

Fürst Medisinsk Laboratorium
Genital Chlamydia trachomatis-infeksjon er den vanligste seksuelt overførbare bakterieinfeksjonen i Skandinavia. Ubehandlet kan infeksjonen føre til bekkeninfeksjon med $ø k t$ risiko for kroniske bekkensmerter, ekstrauterin graviditet og infertilitet (1). Andelen positive $\mathrm{C}$ trachomatis-analyser i Europa har vært jevnt økende siden 1995 (2). Unntaket er i Sverige, der det var en uventet nedgang i antall positive i siste halvdel av 2006. Nedgangen ble etter hvert forklart med metodeproblemer som ga en høy andel falskt negative $\mathrm{C}$ trachomatis-analysesvar (3). Diagnostikkproblemene var forårsaket av en $\mathrm{C}$ trachomatis-variant, som fikk navnet «new variant» (nvC trachomatis) og som også går under navnet «Swedish variant». nvC trachomatis har en delesjon i sitt kryptiske plasmid. Dette plasmidet finnes i nær sagt alle C trachomatis-bakterier, i opptil ti kopier per celle, og er derfor et foretrukket mål for diagnostiske tester. Delesjonen i nvC trachomatis fjernet målområdet for laboratorietestene fra Roche Diagnostics og Abbott. I Sverige ga denne delesjonen spesielt store utslag i diagnostikken da testene fra Roche Diagnostics dominerte på laboratoriene. Overvåking av nvC trachomatis i Sverige viste at omfanget av mutanten varierte fra $25 \%$ i Malmö opp til $80 \%$ i Falun (4).

I Norge studerte vi forekomsten av nvC trachomatis i perioden 29.11.2006-9.2. 2007 og fant at denne var svært lav, under $0,5 \%$ (5). Dette, kombinert med at C trachomatistestene fra Roche Diagnostics ikke har vært like utbredt i Norge som i Sverige, førte til at den nasjonale overvåkingen av nvC trachomatis i Norge i stor grad har vært begrenset til vår analyseaktivitet på Fürst Medisinsk Laboratorium. Vi har analysert $\mathrm{C}$ trachomatis-prøver med en egenutviklet test $\mathrm{i}$ tillegg til rutinetest fra Roche Diagnostics. Begrunnelsen for dobbeltanalyseringen har vært å sikre seg mot falskt negative analysesvar, men dette arbeidet har samtidig gitt verdifulle epidemiologiske data rundt nvC trachomatis.

I denne artikkelen presenterer vi data fra dobbeltanalyseringen. Roche har nå modifisert metoden sin, og fra og med juli/august 2008 vil ikke analyser fra Roche Diagnostics gi falskt negative svar grunnet nvC trachomatis.

\section{Materiale og metode}

Studien sammenfatter analysesvar fra vårt laboratorium i perioden 1.1.2007-30.6. 2008 og inkluderer alle pasientprøver der undersøkelse for $\mathrm{C}$ trachomatis var rekvi- rert. Eksklusjonskriterier ble ikke definert. Deler av materialet (frem til 9.2. 2007) er tidligere publisert i (5).

\section{Laboratoriemetoder}

Laboratorieanalyse av urinprøver ble utført ved å samle de første 5-10 ml. DNA ble isolert med instrumentet MagNA Pure (Roche Diagnostics, Mannheim, Tyskland) fra $200 \mu \mathrm{l}$ urin. Elueringsvolumet var 100 $\mu 1$. Deteksjon av C trachomatis ble utført på $25 \mu \mathrm{l}$ av isolert DNA med Cobas TaqMan 48 (Roche Diagnostics). Deteksjon av nvC trachomatis ble utført med egenutviklet metode på $10 \mu \mathrm{l}$ av isolert DNA på et 7500 sanntid polymerasekjedereaksjons (PCR)instrument (Applied Biosystems, Foster City, California) med primere og prober rettet mot både det kryptiske plasmidet og bakteriegenomet som beskrevet i tidligere artikkel med tilhørende referanser (5). Der hvor analysen var negativ på TaqMan 48, men positiv på egenutviklet metode, ble ytterligere en sanntid PCR utført for å verifisere tilstedeværelse av nvC trachomatis ved bruk av primerne «CtCpDel-FAMP1 (CGATTTCTAAGCAGGAATGGA)», «CtCpDel-RAMP1 (TTTTTCTGGCAACAGAATATGAA)» og proben «CtCpDelProbel (FAM-CTCTTCCCCAGAACAAACGGATCC-TAMRA)». Verifiseringsanalysen ble validert mot DNA-sekvensering av PCR-produktet. Alle oligonukleotidprimere, TaqMan-prober og sanntid PCR Master Mix ble kjøpt fra Applied Biosystems. Avidentifiserte pasientdata ble overført til både Microsoft Excel og SPSS og analysert.

\section{Resultater}

Vi undersøkte til sammen 23726 pasienter for C trachomatis- og nvC trachomatis-

\section{Hovedbudskap}

- En ny variant av Chlamydia trachomatis, nvC trachomatis, er oppdaget i Sverige

- nvC trachomatis ga falskt negative svar ved bruk av enkelte analysemetoder

- Andelen positive prøver som var nvC trachomatis økte fra $1 \%$ til 3,2\% fra første kvartal 2007 til andre kvartal 2008

- Sammenliknet med Sverige er denne andelen liten 
infeksjon i perioden f.o.m. januar 2007 t.o.m. juni 2008. Totalt $54 \%$ var menn. Median alder for de med positivt analysesvar var 25 år. I undergruppen med positivt $\mathrm{nvC}$ trachomatis-analysesvar var det tilsvarende fordeling av kvinner og menn, og median alder var 24 år. 11,2\% av prøvene var positive for $\mathrm{C}$ trachomatis. 61 ble identifisert med nvC trachomatis, 2,3\% av totalantallet positive i perioden. Andelen av positive prøver med nvC trachomatis økte fra $1,0 \%$ i første kvartal 2007 til 3,2\% i andre kvartal 2008 (fig 1).

\section{Diskusjon}

Andelen som testet positivt på $\mathrm{C}$ trachomatis er betydelig høyere enn i normalbefolkningen (6). Det skyldes i hovedsak at vi mottar en stor andel av prøvene våre fra Olafiaklinikken som blir aktivt oppsøkt av en selektert gruppe pasienter. Fra Olafiaklinikken mottar vi i tillegg kun prøver fra de pasientene som har vært til konsultasjon hos lege. Pasientene er derfor selektert på grunnlag av symptomer på, eller mistanke om, seksuelt overførbar infeksjon, noe som forklarer den høye andelen som var positiv. Denne høye andelen er $\mathrm{i}$ våre øyne et godt utgangspunkt for å studere forekomsten av nvC trachomatis.

I Norge har $\mathrm{C}$ trachomatis-analyser fra Roche Diagnostics mindre utbredelse enn i Sverige. Mange laboratorier bruker en analysemetode fra Becton, Dickinson and Company (Franklin Lakes, New Jersey), og denne analyseplattformen har ikke vært berørt av nvC trachomatis-problematikken. Dette er kanskje hovedgrunnen til at man ikke har sett behovet for omfattende overvåking av $\mathrm{nvC}$ trachomatis i Norge. Dessuten har man antatt at forekomsten her i Norge har vært lav basert på vår publikasjon tidlig i 2007 (5). Likevel fantes det en klar risiko for å få falskt negative analysesvar for alle laboratorier som brukte analyser fra Roche Diagnostics, og dette var bakgrunnen for at vi bestemte oss for å dobbeltanalysere alle våre $\mathrm{C}$ trachomatis-prøver. Så vidt vi vet var vi det eneste norske laboratoriet som valgte å gjøre dette. Den lave, men likevel jevnt økende andelen av nvC trachomatis-positive prøver indikerer at det er en liten, men ikke ubetydelig risiko for at det kan ha forekommet falskt negative analysesvar fra laboratorier som i denne perioden benyttet analyser fra Roche Diagnostics alene. Vi understreker imidlertid at siden Roche nå har modifisert metoden sin, vil ikke lenger analyser fra Roche Diagnostics gi falskt negative svar grunnet nvC trachomatis.

Vi fant en andel positive på $1-3,2 \%$, noe som tyder på en langsom økning. Dette synes naturlig, da det i Sverige rapporteres at nvC trachomatis fremdeles utgjør opp mot $40 \%$ av de som tester positivt (7). Sammenliknet både med nåværende prevalens og med tidligere prevalenstall på $25-80 \%$, er andelen i vårt opptaksområde liten. I tillegg har vi mottatt prøver der pasienten ikke har hatt norsk personnummer. Dersom det finnes svensker blant disse pasientene, noe vi mener er sannsynlig, kan man ikke med sikkerhet vite om pasienten er smittet i Sverige eller i Norge. Våre rapporterte tall er derfor ikke nødvendigvis en nøyaktig beskrivelse av smitteoverføring til nordmenn. Prevalensen av smittede nordmenn er antakeligvis lavere enn 3,2\%. Den samme begrensede spredningen er blitt observert i Danmark (8), og nvC trachomatis er ikke blitt funnet $\mathrm{i}$
Irland (9), Nederland (10) eller Frankrike (11). En grunn til denne begrensede spredningen kan muligens være at risikopersoner i Sverige i stor grad finner sexpartnere i sitt nabolag (12). Eller kanskje kan det skyldes at personer med sexpartnere $i$ mange land som ellers ville bidratt til spredning, hittil ikke har vært smittet av nvC trachomatis.

Epidemiologisk er den begrensede spredningen av nvC trachomatis et lite mysterium. nvC trachomatis ble oppdaget på grunnlag av en uforklarlig nedgang i antall $\mathrm{C}$ trachomatis-tilfeller i Sverige. Dette viser at epidemiologisk overvåking er viktig - og at man finner bare det man leter etter. Denne historien viser også at en diagnostisk test må være robust, gjerne treffe flere målsekvenser i den patogene mikroorganismen og samtidig reevalueres jevnlig.

Oppgitte interessekonflikter: Ingen

\section{Litteratur}

1. Peipert JF. Clinical practice. Genital chlamydial infections. N Engl J Med 2003; 349: 2424-30.

2. Low N. Current status of chlamydia screening in Europe. Euro Surveill 2004; 8: 2566.

3. Ripa T, Nilsson P. A variant of Chlamydia trachomatis with deletion in cryptic plasmid: implications for use of PCR diagnostic tests. Euro Surveill 2006; 11: E061109.

4. Herrmann B. A new genetic variant of Chlamydia trachomatis. Sex Transm Infect 2007; 83: 253-4.

5. Moghaddam A, Reinton N. Identification of the Swedish Chlamydia trachomatis variant among patients attending a STI clinic in Oslo, Norway. Euro Surveill 2007; 12: E070301.

6. MSIS-rapport nr. 10/2009. Oslo: Folkehelseinstituttet, 2009. www. fhi.no/artikler/?id=77062 (26.9.2009).

7. Hadad R, Fredlund H, Unemo M. Evaluation of the new COBAS TaqMan CT Test v2.0 and the impact on the proportion of the new variant of Chlamydia trachomatis (nvCT) by introduction of diagnostics detecting nvCT (LightMix 480HT PCR) in Orebro county, Sweden. Sex Transm Infect 2009; 85: $190-3$.

8. Westh $\mathrm{H}$, Jensen JS. Low prevalence of the new variant of Chlamydia trachomatis in Denmark. Sex Transm Infect 2008; 84: 546-7.

9. Lynagh Y, Crowley B, Walsh A. Investigation to determine if newly-discovered variant of Chlamydia trachomatis is present in Ireland. Euro Surveill 2007: 12: E070201.

10. de Vries HJ, Catsburg A, van der Helm JJ et al. No indication of Swedish Chlamydia trachomatis variant among STI clinic visitors in Amsterdam. Euro Surveill 2007: 12: E070208.

11. de Barbeyrac B, Raherison S, Cado S et al. French situation concerning the Swedish Chlamydia trachomatis variant. Euro Surveill 2007; 12: E11-2.

12. Nordvik MK, Liljeros F, Osterlund A et al. Spatial bridges and the spread of Chlamydia: the case of a county in Sweden. Sex Transm Dis 2007; 34: 47-53. 